\title{
PENANAMAN PENDIDIKAN KARAKTER RELIGUS PADA PESERTA DIDIK MADRASAH IBTIDAIYAH
}

\author{
Ary Purwanto' ${ }^{1}$ Abdul Wachid B.S ${ }^{2}$ \\ 1,2 Pascasarjana IAIN Purwokerto, IAIN Purwokerto, Indonesia \\ 201763002@mhs.iainpurwokerto.ac.id ${ }^{1}$ abdulwachidbs@gmail.com²
}

\begin{tabular}{l} 
INFO ARTIKEL \\
\hline Riwayat Artikel: \\
Diterima: 02-02-2021 \\
Disetujui: $30-04-2021$ \\
\end{tabular}

\section{Kata Kunci:}

Pendidikankarakter religius

Ekstrakurikuler Adzan

Madrasah Ibtidaiyah

Keywords:

ReligiousCharacterEducation

AdhanExtracurricular Activities

Madrasagh Ibtidaiyah

\begin{abstract}
ABSTRAK
Abstrak: didik di Madrasah Ibtidaiyah Muhammadiyah Pesayangan salah satunya dilakukan melalaui kegiatan ekstrakurikuler Adzan yang diikuti oleh seluruh peserta didik laki-laki mulai dari kelas 1 sampai dengan kelas 6. Kegiatan yang sangat disambut baik oleh orangtua peserta didik ini diharapkan mampu menguatkan karakter religius peserta didik. Penelitian ini menggunakan rancangan penelitian kualitatif. Pengumpulan data dilakukan melalui metode wawancara terhadap guru, Kepala Madrasah serta orangtua peserta didik dan metode dokumentasi dilakukan guna mengamati hasil pelaksanaan kegiatan ekstrakurikluer adzan tersebut.
\end{abstract}

\begin{abstract}
:
The planting of religious character education that is trying to be instilled in students at the Muhammadiyah Pesayangan Ibtidaiyah Madrasah is one of them carried out through extracurricular adhan activities which are followed by all male students starting from grade 1 to grade 6. This activity is very welcomed by the parents of these students. is expected to be able to strengthen the religious character of students. This study used a qualitative research design. The data was collected through the interview method with the teacher, the head of Madrasah and the parents of the students and the documentation method was used to observe the results of the extracurricular activity of the adhan.
\end{abstract}

\section{A. LATAR BELAKANG}

Dalam dunia pendidikan nasional di Indonesia, terdapat salah satu wacana utama yang sering dibahas yaitu mengenai pendidikan karakter. Semua jenis kegiatan yang ada di dalam proses pembelajaran di sekolah, harus mengacu kepada pendidikan tersebut. Karakter siswa sangat dibutuhkan dan sangat penting, untuk menciptakan pendidikan yang sesuai. Oleh karena itu, pendidikan yang membangun nilai-nilai karakter atau moral di kalangan peserta didik harus selalu mendapatkan perhatian. Pendidikan karakter yang ditanamkan mulai dari kanak-kanak sampai dengan remaja merupakan wadah yang sangat penting untuk membangun generasi muda yang memiliki moral/akhlak yang mulia, sikap gotong royong dan toleransi yang tinggi.

Hal tersebut sesuai dengan fungsi dan tujuan Pendidikan Nasional sebagaimana yang tercantum dalam Undang-Undang Sistem Pendidikan Nasional
Nomor 20 Tahun 2003 Bab II Pasal 3 berbunyi: "Pendidikan nasional berfungsi mengembangkan kemampuan dan membentuk watak serta peradaban bangsa yang bermartabat dalam rangka mencerdaskan kehidupan bangsa, bertujuan untuk berkembangnya potensi peserta didik agar menjadi manusia yang beriman dan bertakwa kepada Tuhan Yang Maha Esa, berakhlak mulia, sehat, berilmu, cakap, kreatif, mandiri, dan menjadi warga negara yang demokratis serta bertanggung jawab".

Pendidikan karakter menurut Thomas Lickona (2013: 51) mengandung tiga unsur pokok yaitu mengetahui kebaikan (knowing the good), mencintai kebaikan (desiring the good), dan melakukan kebaikan (doing the good). Pendidikan karakter tidak hanya sekedar mengajarkan mana yang benar dan mana yang salah kepada anak, tetapi lebih daripada itu pendidikan karakter menanamkan kebiasaan (habituation) tentang 
yang baik sehingga peserta didik paham, mampu merasakan, dan mau melakukan yang baik.

Lickona menyampaikan paling tidak ada tujuh alasan mengapa pendidikan karakter itu perlu untuk dipelajar. Ketujuh alasan alasan tersebut yaitu:

1. Merupakan cara terbaik untuk menjamin anakanak (siswa) memiliki kepribadian yang baik dalam kehidupannya.

2. Salah satu cara untuk meningkatkan prestasi akademik.

3. Membantu sebagian siswa tidak dapat membentuk karakter yang kuat bagi dirinya di tempat lain.

4. Menyiapkan diri siswa untuk menghormati pihak atau orang lain dan dapat hidup dalam masyarakat yang beragam.

5. Pendidikan karakter bersumber dari akar masalah yang berkaitan dengan problem moralsosial, seperti ketidaksopanan, ketidakjujuran, kekerasan, pelanggaran kegiatan seksual, dan etos kerja (belajar) yang rendah.

6. Menyiapkan diri siswa untuk menyongsong perilaku di tempat kerja.

7. Merupakan pembelajaran nilai-nilai budaya yang merupakan bagian dari kerja peradaban.

Pendidikan karakter adalah sebuah upaya atau usaha yang memang telah direncanakan untuk mewujudkan suasana dan juga proses di dalam pemberdayaan potensi, atau pembudayaan setiap siswa dalam membangun sebuah karakter sebagai warga Negara Indonesia yang baik disebut dengan pendidikan karakter. Ketika kita memiliki usaha atau upaya tersebut, maka nantinya akan tercipta seorang warga negara yang memiliki moral sekaligus akhlak yang baik. Suatu bentuk dari kegiatan yang dilakukan oleh manusia, yang dengan suatu tindakan yang sifatnya mendidik bagi generasi yang akan datang juga merupakan definisi dari pendidikan serta karakter itu. Pengertian lainnya yaitu sebuah sistem pendidikan, yang di dalamnya terdapat tujuan yaitu penanaman nilai karakter yang mencakup segala hal seperti kesadaran atau kemauan, komponen dasar pengetahuan, hingga tindakan untuk melaksanakan nilai itu sendiri. Ada 18 karakter bangsa yang menjadi target sekaligus indikator keberhasilan pendidikan karakter bagi bangsa meliputi: 1) Religius, 2) Jujur, 3) Toleransi, 4) Disiplin, 5) Kerja keras, 6) Kreatif, 7) Mandiri, 8) Demokratis, 9) Rasa ingin tahu, 10) Semangat kebangsaan, 11) Cinta tanah air, 12) Menghargai prestasi, 13) Bersahabat/Komunikatif, 14) Cinta damai, 15) Gemar membaca, 16) Peduli lingkungan, 17) Peduli sosial, dan 18) Tanggung jawab (Badrus Zaman, 2019: 27).

Kurangnya pendidikan karakter di dalam kehidupan masyarakat akan membuat seseorang memiliki sikap yang negatif, contohnya kasuskasus sosial di masyarakat yang meliputi kekerasan pada anak-anak, pergaulan bebas, pencurian, kekerasan sesual, penyalahgunaan obat terlarang dan masih banyak lagi yang lainnya. Hal ini tentunya tidak diinginkan oleh siapaun juga.

Salah satu tujuan penyelenggaraan pendidikan di Madrasah Ibtidaiyah Muhammadiyah Pesayangan adalah untuk menghasilkan lulusan yang memiliki karakter, kecakapan, keterampilan, dan pengetahuan yang baik untuk mengembangkan potensi diri secara optimal, sehingga nantinya lulusannya memiliki kemampuan untuk bertahan dalam pendidikan lanjutan dan bermanfaat bagi lingkungan sekitarnya.

Karakter yang tercermin dalam perbuatan atau prilaku peserta didik baik di sekolah maupun di rumah diharapkan mampu membantu membangun kesan yang baik di hadapan masyarakat, sehingga masyarakat lebih percaya lagi untuk menyekolahkan anaknya di Madrasah Ibtidaiyah Muhammadiyah Pesayangan.

Madrasah Ibtidaiyah Muhammadiyah Pesayangan ini berusaha menanamkan pendidikan karakter religus melalui kegiatan ekstrakurikuler adzan. Kegiatan ekstrakurikuler adzan ini telah dilaksanakan mulai tahun Pelajaran 2019/2020, namun telah dihentikan saat terjadi Pandemi Covid-19.

\section{B. METODE PENELITIAN}

\section{Tahapan Penelitian}

Dalam penelitian ini, yang digunakan adalah penelitian kualitatif. Dalam penelitian kualitatif data yang dikumpulkan bukan angka-angka, akan tetapi berupa kata-kata atau gambaran. Data yang dimaksud berasal dari wawancara, catatan lapangan, foto, dokumen pribadi dan lainnya (Lexy J. Moleong, 2010: 11). Oleh karena itu dalam penelitian ini menggunakan pendekatan deskriptif. Penelitian deskriptif merupakan penelitian yang menggambarkan fenomena atau populasi tertentu yang diperoleh peneliti dari subjek yang berupa individu, organisasional atau perspektif yang lain. Adapun tujuannya adalah untuk menjelaskan aspek yang relevan dengan fenomena yang diamati dan menjelaskan karakteristik fenomena atau masalah yang ada. 
Penelitian ini dilakukan di Madrasah Ibtidaiyah Muhammadiyah Pesayangan Kecamatan Purbalingga Kabupaten Purbalingga. Dan untuk mendapatkan datadata yang diperlukan, peneliti menggunakan dua metode, yaitu: wawancara dan dokumentasi. Pada proses ini peneliti mengubah dan mengolah data mentah menjadi data bermakna yang mengarah pada kesimpulan.

Dalam penelitian ini analisis data dimulai dengan mencari data mentah menggunakan metode wawancara dan dokumentasi. Datadata penelitian selanjutnya dianalisis setelah melewati langkah berikut:

1. Melakukan wawancara terhadap guru dan Kepala Madrasah, dan orang tua peserta didik terkait pelaksanaan kegiatan ekstrakurikuler adzan yang dilakukan selama ini.

2. Melakukan dokumentasi terhadap penanaman karakter religius peserta didik, yaitu dengan cara berkomunikasi dengan salah satu orang tua peserta didik berkaitan dengan karakter religius peserta didik.

Melihat kondisi yang masih di musim Pandemi Covid-19 ini, maka untuk subjek penelitian hanya akan diambil satu subjek saja. Meskipun demikian, penulis yakin bahwa tujuan penelian yang ingin penulis peroleh yaitu mendeskripsikan penanaman pendidikan karakter religus pada peserta didik Madrasah Ibtidaiyah Muhammadiyah Pesayangan tetap berhasil.

\section{HASIL DAN PEMBAHASAN}

\section{Pendidikan Karakter Religius}

\subsection{Pendidikan Karakter}

Menurut Masnur Muslich menyatakan bahwa pendidikan karakter adalah suatu sistem pemahaman nilai-nilai karakter kepada warga sekolah yangmeliputi komponen pengetahuan, kesadaran, kemauan, dan tindakan untuk melaksanakan nilai-nilai tersebut, baik terhadap Tuhan Yang Maha Esa (YME), diri sendiri, sesama, lingkungan, maupun kebangsaan sehingga menjadi manusia insan kamil. Sementara itu, Bagus Mustakim menyatakan bahwa pendidikan karakter dapat dimaknai sebagai suatu proses internalisasi sifat-sifat utama yang menjadi ciri khusus dalam suatu masyarakat ke dalam diri peserta didik sehingga dapat tumbuh dan berkembang menjadi manusia dewasa sesuai dengan nilainilai budaya masyarakat setempat.

Dony Kusuma menyampaikan bahwa pendidikan karakter merupakan dinamika pengembangan kemampuan yang berkesinambugan dalam diri manusia untuk mengadakan internalisasi nilai-nilai sehingga menghasilkan disposisi aktif, stabil dalam diri individu.

Selanjutnya menurut Sri Judiani bahwa pendidikan karakter ialah pendidikan yang mengembangkan nilai-nilai karakter pada peserta didik sehingga mereka memiliki nilai dan karakter sebagai karakter dirinya, menerapkan nilai-nilai tersebut dalam kehidupan dirinya, sebagai anggota masyarakat dan warga negara yang religius, nasionalis, produktif, dan kreatif.

Senada dengan pendapat itu, Agus Wibowo menyatakan bahwa pendidikan karakter adalah pendidikan yang menanamkan dan mengembangkan karakter-karakter luhur kepada anak didik, sehingga mereka memiliki karakter luhur itu, menerapkan dan mempraktikkan dalam kehidupannya, entah dalam keluarga, sebagai anggota masyarakat dan warga negara.

Sedangkan Lickona (1991) menyatakan pendapatnya bahwa pendidikan karakter adalah suatu usaha yang disengaja untuk membantu seseorang sehingga ia dapat memahami, memperhatikan, dan melakukan nilai-nilai etika yang inti

Berdasarkan beberapa pendapat para ahli di atas, penulis menyimpulkan bahwa pendidikan karakter ialah sebuah upaya menumbuhkan dan mengembangkan nilai-nilai luhur kepada peserta didik. Hal terebut dilakukan agar mereka mengetahui, menginternalisasi, dan menerapkan nilai-nilai luhur tersebut dalam kehidupannya dalam keluarga, masyarakat, bangsa, dan negara.

\subsection{Religius}

Menurut Kemendiknas ada 18 nilai pendidikan budaya dan karakter bangsa yaitu:

a. Religius: sikap dan perilaku patuh dalam melaksanakan ajaran agama yang dianutnya, toleran terhadap pelaksanaan ibadah agama lain, serta hidup rukun dengan pemeluk agama lain.

b. Jujur: perilaku yang didasarkan pada upaya menjadikan dirinya sebagai orang yang selalu dapat dipercaya dalam perkataan, tindakan dan pekerjaan. 
c. Toleransi: sikap dan tindakan yang menghargai perbedaan agama, suku, etnis, pendapat, sikap, dan tindakan orang lain yang berbeda dari dirinya.

d. Disiplin: tindakan yang menunjukkan perilaku tertib dan patuh pada berbagai ketentuan dan peraturan.

e. Kerja Keras: perilaku yang menunjukkan upaya sungguh-sungguh dalam mengatasi berbagai hambatan belajar dan tugas, serta menyelesaikan tugas dengan sebaikbaiknya.

f. Kreatif: berpikir dan melakukan sesuatu untuk menghasilkan cara atau hasil baru dari apa yang telah dimiliki.

g. Mandiri: sikap dan perilaku yang tidak mudah tergantung pada orang lain dalam menyelesaikan tugas-tugas.

h. Demokratis: cara berpikir, bersikap, dan bertindak yang menilai sama hak dan kewajiban dirinya dan orang lain.

i. Rasa Ingin Tahu: sikap dan tindakan yang selalu berupaya untuk mengetahui lebih mendalam dan meluas dari apa yang dipelajarinya, dilihat, dan didengar.

j. Semangat Kebangsaan: cara berpikir, bertindak, dan wawasan yang menempatkan kepentingan bangsa dan negara di atas kepentingan diri dan kelompoknya.

k. Cinta Tanah Air: cara berpikir, bersikap, dan berbuat yang menunjukkan kesetiaan, kepedulian, dan penghargaan yang tinggi terhadap bahasa, lingkungan fisik, sosial, budaya, ekonomi, dan politik bangsanya.

l. Menghargai Prestasi: sikap dan tindakan yang mendorong dirinya untuk menghasilkan sesuatu yang berguna bagi masyarakat, dan mengakui, dan menghormati keberhasilan orang lain.

m. Bersahabat dan Komunikatif: tindakan yang memperlihatkan rasa senang berbicara, bergaul, dan bekerjasama dengan orang lain.

n. Cinta Damai: sikap, perkataan, dan tindakan yang menyebabkan orang lain merasa senang dan aman atas kehadirannya.

o. Gemar Membaca: kebiasaan menyediakan waktu untuk membaca berbagai bacaan yang memberikan kebajikan baginya.

p. Peduli Lingkungan: sikap dan tindakan yang selalu berupaya mencegah kerusakan pada lingkungan alam di sekitarnya, dan mengembangkan upaya-upaya untuk memperbaiki kerusakan alam yang sudah terjadi. q. Peduli Sosial: sikap dan tindakan yang selalu ingin memberi bantuan bagi orang lain dan masyarakat yang membutuhkan.

r. Tanggung jawab: sikap dan perilaku seseorang untuk melaksanakan tugas dan kewajibannya yang seharusnya dia lakukan, terhadap diri sendiri, masyarakat, lingkungan alam, sosial, dan budaya), negara dan Tuhan Yang Maha Esa.

Pada penelitian yang dilakukan oleh penulis ini, penulis hanya akan berkonsetrasi pada satu nilai karakter saja yaitu religius. Sehingga diharapkan hasil dari penelitian ini akan lebih maksimal lagi.

\section{Ekstrakurikuler Adzan}

2.1.Ekstrakurikuler

Menurut Depdiknas (2003: 16) ekstrakurikuler adalah kegiatan yang diselenggarakan untuk memenuhi tuntutan penguasaan bahan kajian dan pelajaran dengan alokasi waktu yang diatur secara tersendiri berdasarkan kebutuhan.

Ada banyak jenis ekstrakurikuler yang biasa diajarkan di sekolah,misalnya seperti ; komputer, pramuka, karate, sepak bola, bulu tangkis dan masih banyak lagi jenisnya yang pelaksanaannya diluar jam pelajaran atau tatap muka. Dan menurut peneliti kegiatan pelatihan adzan juga termasuk didalamnya.

2.2.Adzan

Adzan secara lughawi (etimologi): menginformasikan semata-mata. Sedangkan secara istilah (terminologi) adalah: menginformasikan (memberitahukan) tentang waktu-waktu salat dengan kata-kata tertentu. Adzan ini telah diperintahkan sejak pada tahun pertama dari Hijrah Nabi ke Madinah.

Selain itu, adzan juga bermakna seruan atau pangilan. Makna ini digunakan ketika Nabi Ibrahim 'alaihissalam diperintahkan untuk memberitahukan kepada manusia untuk melakukan ibadah haji yang terdapat dalam AlQuran Surat Al-Hajj Ayat 27 :

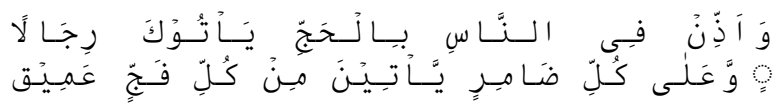

Artinya: Dan panggilah manusia untuk mengerjakan haji, niscaya mereka akan datang kepadamu dengan berjalan kaki, dan mengendarai unta yang kurus yang datang dari segenap penjuru yang jauh,( QS. Al-Hajj : 27)

Jadi adzan adalah suatu pemberitahuan seorang mu'adzin (orang yang adzan) kepada manusia mengenai masuknya waktu salat fardhu. 


\section{Madrasah Ibtidaiyah}

MI adalah satuan pendidikan formal yang menyelenggarakanpendidikan umum dengan kekhasan agama Islam yang terdiri dari 6(enam) tingkat pada jenjang pendidikan dasar. Madrasah Ibtidaiyah (MI)ini setara dengan Sekolah Dasar (SD) yang wajib ditempuh oleh seluruh anak-anak Indonesia.MI merupakan jenjang lanjutan setelah RA.

Pada jenjang madrasah ibtida'iyah ini siswa menerima pelajaran seperti halnya sekolah umum dengan tambahan pelajaran agama seperti Fiqih, Aqidah Akhlaq, Al-Qur'an Hadits dan juga Bahasa Arab. Untuk pelajaran Sejarah Kebudayaan Islam baru diberikan mulai kelas 3 .

Madrasah Ibtidaiyah yang menjadi tempat penelitian ini adalah Madrasah Ibtidaiyah Muhammadiyah Pesayangan Kelurahan Purbalingga Lor Kecamatan Purbalingga Kabupaten Purbalingga.

Perlu diketahui bersama, bahwa dalam proses pembelajaran pendidikan karakter setidaknya ada tiga tahapan strategi yang harus dilalui, yaitu:

\section{a. Moral Knowing/Learning to Know}

Tahapan ini merupakan langkah pertama dalam pendidikan karakter. Dalam tahapan ini tujuan diorientasikan pada penguasaan pengetahuan tentang nilai-nilai. Siswa harus mampu membedakan nilai-nilai akhlak mulia dan akhlak tercela serta nilai-nilai universal; memahami secara logis dan rasional (bukan secara dogmatis dan doktriner) pentingnya akhlak mulia dan bahaya akhlak tercela dalam kehidupan; mengenal sosok Nabi Muhammad SAW sebagai figur teladan akhlak mulia melalui hadits-hadits dan sunnahnya.

Siswa diberi pemahaman dan pengertian mana saja moral yang positif dan mana saja moral yang negatif. Jangan sampai mereka salah dalam menentukan pilihan dalam pendidikan karakter ini.

b. Moral Loving/Moral Feeling

Tahapan ini dimaksudkan untuk menumbuhkan rasa cinta dan rasa butuh terhadap nilai-nilai akhlak mulia. Dalam tahapan ini yang menjadi sasaran guru adalah dimensi emosional siswa, hati, atau jiwa, bukan lagi akal, rasio dan logika. Guru menyentuh emosi siswa sehingga tumbuh kesadaran, keinginan, dan kebutuhan terhadap nilai-nilai akhlak mulia dalam dirinya. Untuk mencapai tahapan ini guru bisa memasukinya dengan kisah-kisah yang menyentuh hati, modelling, atau kontemplasi. Diharapkan pula siswa mampu menilai dirinya sendiri (muhasabah) atas kekurangannya.

Dengan tumbuhnya rasa cinta dan rasa butuh terhadap nilai-nilai akhlak mulia, maka akan menumbuhkan kesadaran siswa untuk menunjukan moral yang baik / tidak melakukan kesalahan karena nilai-nilai yang baik telah mengakar kuat di dalam sanubarinya. Dan bila mereka melakukan kesalahan atau perbuatan yang bertentangan dengan nilai-nilai moral maka mereka akan segera kembali terhadap akhlaknya.

Dengan moral positif yang dilakukan oleh siswa terhadap dirinya sendiri maka ia juga akan memberi penghargaan yang positif terhadap orang lain. Penghargaan yang positif terhadap dirinya sendiri menunjukan bahwa ia memiliki moral yang baik.

c. Moral Doing/Learning to do

Pada tahapan ini diharapkan siswa telah mempraktikkan nilai-nilai akhlak mulia dalam kehidupannya. Selama perubahan akhlak belum terlihat dalam perilaku anak walau sedikit, selama itu pula kita memiliki setumpuk pertanyaan yang harus selalu dicari jawabannya.

Teladan adalah guru yang paling baik dalam menanamkan nilai. Guru di sekolah, orang tua di rumah, dan masyarakat di lingkungan sekitar merupakan teladan utama bagi siswa. Selain memberi pengajaran dan penanaman moral, mereka juga bertanggungjawab untuk memberikan pembiasaan dan pemotivasian sehingga siswa diharapkan mampu untuk mempraktikkan akhlak-akhlak mulia.

Dari hasil dari pelaksanaan wawancara dengan guru dan Kepala Madrasah, dan orang tua peserta didik hari Senin tanggal 19 Oktober 2020 diperoleh informasi bahwa :

1) Penanaman karakter religius di Madrasah Ibtidaiyah Muhammadiyah Pesayangan sebenarnya sudah diterapkan sebelum program ektrakurikuler adzan digulirkan. Diantaranya adalah dengan dilaksanakannya kegiatan Baca Tulis Al-Qur'an di jam pertama, shalat dhuha sebelum waktu istirahat pertama, dan shalat dhuhur berjama'ah di Masjid.

Kegiatan-kegiatan ini diikuti oleh seluruh siswa. Selain itu, tentunya dewan guru juga sudah memberikan sifat keteladanan (modeling) terlebih dahulu. Karena seorang guru pastinya paham betul bahwa guru seyogyanya memiliki sifat tertentu sebab guru itu diibaratkan dengan naskah asli yang siap untuk dikopi. Guru harus senantiasa memberi teladan bagi siswa, karena gurulah yang memiliki 
tanggungjawab untuk menanamkan nilai-nilai lahiriah dan batiniah di sekolah. Jadi tahap Moral Knowing/Learning to Know dan Moral Loving/Moral Feeling sudah berjalan dengan baik di Madrasah Ibtidaiyah Muhammadiyah Pesayangan.

2) Meskipun sudah banyak kegiatan yang mengarah pada penanaman karakter religius peserta didik, namun karena masih perlu adanya peningkatan maka dibuatlah kegiatan ekstrakurikuler baru yaitu ekstrakurikuler adzan. Dengan tujuan peserta didik akan semakin religus dan lebih bisa bermanfaat lagi di lingkungan masyarakat / rumah terutama di Mushola/Masjid sekitar tempat tinggal peserta didik. Hal ini juga didasari karena memang ada kecenderungan regenerasi muadzin mulai melambat di sekitar lingkungan tempat tinggal siswa. Pelaskanaan kegiataan ekstrakurikuler adzan dilakukan seminggu sekali di hari Rabu dengan peserta seluruh siswa laki-laki mulai dari kelas II sampai dengan kelas VI. Dalam kegiatan ini baik Kepala Madrasah, guru pendamping, maupun pelatih adzan selalu memberikan semangat kepada peserta didik agar mengikuti kegiatan ekstrakurikuler adzan dengan baik dan penuh konsentrasi. Dan alhamdulillah peserta didik pun mengikuti kegiatan dengan baik dan penuh konsentrasi. Pelaksanaan kegiatan ekstrakuriker adzan di Madrasah Ibtidaiyah Muhammadiyah Pesayangan bisa dilihat di https://www.youtube.com/watch?v=RnJJtTbRo3g

3) Dalam proses belajar mandiri pada masa Pandemi Covid-19 ini, peneliti mencoba menggali dengan melakukan wawancara dari salah satu orang tua peserta didik yaitu Ibu Tri Minanti apakah selama masa ini anaknya mempraktekkan hasil dari aktifitasnya mengikuti kegiatan ekstrakurikuler adzan. Hal ini penting dilakukan untuk mengetahui pengembangan karakter religius peserta didik telah terintegrasi ke dalam aspek kehidupan nyata di tengah masyarakat ataukah belum. Sekaligus untuk mengetahui apakah tahap Moral Doing/Learning to do telah terlaksana ataukah belum.

Dari hasil wawancara yang dilakukan melalui WhatsApp diketahui bahwa anaknya tetap melaksanakan shalat berjama'ah di Mushola dan anaknya tersebut juga berani untuk mengumandangkan adzan. Anak tersebut bernama Aji Arzakaty, peserta didik kelas 5 Madrasah Ibtidaiyah Muhammadiyah Pesayangan. Videonya bisa dilihat di https://www.youtube.com/watch?v=YfJu7VhIJAg $\& \mathrm{t}=33 \mathrm{~s}$
Keberanian siswa untuk mengumandangkan adzan yang kemudian menjadi pembiasaan (habituation) siswa merupakan bukti dari dukungan orang tua dan masyarakat, selain dari usaha penanaman karakter yang dilakukan oleh gurunya di sekolah.

\section{SIMPULAN}

Dari hasil penelitian penanaman pendidikan karakter religus pada peserta didik Madrasah Ibtidaiyah Muhammadiyah Pesayangan Kecamatan Purbalingga Kabupaten Purbalingga yang peneliti lakukan dapat disimpulkan bahwa dengan adanya kegiatan ekstrakurikuler adzan maka memiliki dampak yang cukup signifikan dalam penanaman karakter religius peserta didik. Peserta didik ternyata termotivasi untuk melakukan sesuatu dari hasil pemahamannya terhadap makna atau nilai yang telah dipelajarinya terutama karakter religus. Peningkatan karakter religiusitas ini telah terlihat ditandai dengan adanya peningkatan aktifitas spiritualitas peserta didik dengan shalat berjama'ah di Mushola dan didahului dengan beraninya peserta didik untuk mengumandangkan adzan.

Pemberian kesempatan / ruang di masyarakat bagi peserta didik untuk mengumandangkan adzan menjadi salah satu bagian yang cukup penting dalam penanaman karakter religus melalui kegiatan ekstrakurikuler adzan. Karena kalau tidak ada kesempatan / ruang tersebut maka akan sulit bagi peserta didik untuk mengaplikasikannya dalam kehidupan sehari-hari. Dan alhamudlillah ternyata masyarakat pun mendukung kegiatan ini, dengan bukti diberi kesempatannya peserta didik untuk adzan.

Namun tetap perlu diperhatikan juga bahwa guru dan orang tua peserta didik juga memiliki peran yang sangat penting dalam penanaman karakter yaitu sebagai model dan kotrol yang baik bagi peserta didik atau anak-anaknya. Karena perlu diingat bahwa suatu karakter itu tidak dapat dinilai dalam satu waktu saja, melainkan harus terus dilakukan observasi dan identifikasikan dalam keseharian anak, baik di kelas, sekolah, maupun rumah. 


\section{DAFTAR RUJUKAN}

Abdul Majid dan Dian Andayani. Pendidikan Karakter Perspektif Islam. Bandung: Remaja Rosdakarya

Agus Wibowo. 2012 Pendidikan Karakter: Strategi Membangun KarakterBangsa Berperadaban. Yogyakarta : Pustaka Pelajar

Bagus Mustakim. 2011. Pendidikan Karakter: Membangun Delapan KarakterEmas Indonesia Menuju Indonesia Bermartabat. Yogyakarta: Samudra Biru

Depdiknas. 2013. Kurikulum 2004 Standar Kompetensi Sekolah Dasar, Jakarta: Depdiknas

Doni Koesoema A. 2010. Pendidikan Karakter : Strategi Mendidik Anak di ZamanGlobal Jakarta : Gramedia

Kementrian Agama RI. 2015. Madrasah Indonesia: Madrasah Prestasiku, Madrasah Pilihanku. Jakarta : Direktorat Jendral Pendidikan Islam Kementrian Agama RI

Lexy J. Moleong. 2010. Metodologi Penelitian Kualitatif. Bandung: PT Remaja Rosdakarya.

Masnur Muslich. 2011 Pendidikan Karakter: Menjawab Tantangan Krisis Multidimensional. Jakarta: Bumi Aksara

Muchlas Samani \& Hariyanto. 2012. Konsep dan Model Pendidikan Karakter. Bandung: Remaja Rosdakarya

Muhammad Fadlillah dan Lilif Mualifatu Khorida. 2013. Pendidikan KarakterAnak Usia Dini: Konsep \& Aplikasinya dalam PAUD. Yogyakarta: Ar-Ruzz Media

Muhammad Jawad Mughaniyah. 2007. Fiqih Lima Madzhab: Ja'fari, Hanafi, Maliki, Syafi'i, Hambali/Muhammad Jawad Mughniyah. Jakarta : Penerbit Lentera

Siti Asdiqoh. 2019. Implementasi Pendidikan Karakter Pada Siswa Madrasah Aliyah. INSANIA Vol. 25 No. 1 IAIN Salatiga

Thomas Lickona. 2013. Educating for Character: Mendidik untuk Membentuk Karakter. Jakarta: Bumi Aksara

Zubaedi. 2011. Desain Pendidikan Karakter: Konsep dan Aplikasinya dalamLembaga Pendidikan. Jakarta: Kencana 